\title{
Resorption versus secretion in the rat epididymis
}

\author{
T. T. Turner \\ Department of Urology, University of Virginia School of Medicine, Charlottesville, Virginia 22908, \\ U.S.A.
}

\begin{abstract}
Summary. Micropuncture samples were taken from the rete testis, caput epididymidis and cauda epididymidis of anaesthetized adult rats and assayed for total protein, sodium and potassium concentrations. Intraluminal sperm concentrations were determined and used to calculate the amount of fluid resorbed from the efferent duct and epididymal lumen. It was demonstrated that large amounts of protein $(30.2 \mathrm{mg} / \mathrm{ml}$ cauda volume) and sodium (241.8 mequiv./1) and smaller amounts of potassium (19.4 mequiv./1) are resorbed from the rat epididymal lumen between the caput and corpus epididymidis. This occurs despite increases in intraluminal concentrations of protein (from 22 to $28 \mathrm{mg} / \mathrm{ml}$ ) and potassium (from 16 to 50 mequiv./1). Resorption is an important aspect of epididymal control of the intraluminal environment.
\end{abstract}

\section{Introduction}

The microenvironment inside the male excurrent duct system is known to be important to the maturation of spermatozoa (Orgebin-Crist, 1969) and in recent years many studies have demonstrated how that microenvironment is influenced by activities of functions of the efferent ducts or epididymal epithelium. Studies have focussed on (1) characterizing the concentration of intraluminal electrolytes (Levine \& Marsh, 1971; Jenkins, Lechene \& Howards, 1980), carnitine (Hinton, Snoswell \& Setchell, 1979), glycerophosphocholine (Hinton \& Setchell, 1980), myoinositol (Hinton, White \& Setchell, 1980), and proteins (Turner, Plesums \& Cabot, 1979), amongst others; (2) the control of fluid resorption (Wong \& Yeung, 1977; Turner \& Cesarini, 1983), (3) the imposition of a blood-epididymal barrier (Turner, D'Addario \& Howards, 1981; Hinton \& Howards, 1981), or (4) the importance of intraluminal factors on epithelial functions (Cooper, 1980).

Several of the descriptive studies mentioned above have shown increases in concentrations of many intraluminal substances, both elemental and organic, and much attention has been paid to the secretory capacity of the epididymis, especially the secretion of epididymal proteins (e.g. Lea, Petrusz \& French, 1978; Moore, 1980; Flickinger, 1981; Vernon, Muller, Herr, Feuchter \& Eddy, 1982; Brooks, 1983). The epididymis has therefore come to be viewed by many as a primarily secretory organ with relatively little attention paid to its resorptive abilities. The present study was undertaken to examine the degree to which intraluminal constituents are removed from the lumen of the rat epididymis by providing an estimate of net secretion or absorption of proteins, sodium and potassium from the rat epididymal lumen.

The calculations performed herein depend upon the use of intraluminal sperm concentrations as direct markers for intraluminal fluid space. Spermatozoa in the lumen of the excurrent duct system meet the criteria for fluid space markers. That is, they are not appreciably metabolized in $s i t u$, diffused from the lumen, or taken up by epithelial cells. Intraluminal sperm concentrations are therefore a direct indicator of fluid resorption or secretion. If sperm concentrations in the epididymis increase or decrease from one zone to another, then one would expect the concentrations of any other intraluminal substance not diffused, metabolized, or taken up by cells to increase or decrease by the same amount. Using the sperm concentration data and the 
concentrations of other intraluminal substances, one can obtain estimates of net secretion or absorption of those substances throughout the excurrent duct system.

\section{Materials and Methods}

Adult, male Sprague-Dawley rats were anaesthetized by i.p. injection of 5-sec-butyl-5-ethylthiobarbituric acid (Inactin: Byk Guilden, Konstanz, Hamburg, Germany; $100 \mathrm{mg} / \mathrm{kg}$ body wt) and subjected to in-vivo micropuncture as previously described (Howards, Johnson \& Jessee, 1975; Turner, 1979). Cardiac blood was obtained by direct needle aspiration. Sperm concentrations in micropuncture samples of fluid from the rete testis, caput epididymidis and cauda epididymidis were determined with a sperm concentration microassay previously described (Turner \& Cesarini, 1983). Total protein concentrations in the 3 fluids were determined by microassay based on the procedure of Lowry, Rosebrough, Farr \& Randall (1951), and sodium and potassium concentrations were determined after a 1:2000 dilution. Samples were analysed in a IL model 43 flame photometer (Instrumentation Laboratories, Boston, MA).

The data reported in Tables 1 and 2 are based on triplicate analyses of duplicate samples from at least 5 different animals. The formulae used for the several calculations involved were as follows.

$$
\frac{\mathrm{SC}_{\mathrm{D}}-\mathrm{SC}_{\mathrm{P}}}{\mathrm{SC}_{\mathrm{P}}} \times 100=\% \Delta_{\mathrm{SC}}
$$

where $\mathrm{SC}_{\mathrm{D}}=$ mean sperm concentration in any distal zone; $\mathrm{SC}_{\mathrm{P}}=$ mean sperm concentration in any proximal zone, and $\% \Delta_{\mathrm{SC}}=$ percentage change in intraluminal sperm concentration.

$$
1-\left(\frac{\mathrm{SC}_{\mathbf{P}}}{\mathrm{SC}_{\mathrm{D}}}\right) \times 100=\% \mathrm{FR}
$$

where $\% \mathrm{FR}=$ percentage fluid resorption between the proximal and distal zone;

$$
\operatorname{Conc}_{\mathrm{D}}-\left(\frac{\mathrm{SC}_{\mathrm{D}}}{\mathrm{SC}_{\mathrm{P}}} \times \text { Conc }_{\mathrm{P}}=\right) \Delta_{\mathrm{Conc}}
$$

where Conc $\mathrm{C}_{\mathrm{D}}=$ mean concentration of any substance in a distal zone ; and Conc $_{\mathrm{P}}=$ mean concentration of any substance in a proximal zone; and $\Delta_{\text {Conc }}=$ total amount of a substance secreted $(+)$ or absorbed ( - ) between proximal and distal zones per unit of distal zone fluid volume.

$$
\text { Conc }_{\mathrm{P}} \times \frac{\mathrm{SC}_{\mathrm{D}}}{\mathrm{SC}_{\mathrm{P}}}=\widehat{\text { Conc }_{\mathrm{D}}}
$$

where $\widehat{\text { Conc }_{\mathrm{D}}}=$ predicted mean concentration of a substance in a distal zone given a known concentration in a proximal zone.

\section{Results}

The concentrations of total proteins, sodium and potassium in peripheral serum were $72 \cdot 1 \pm 3 \cdot 1$ $\mathrm{mg} / \mathrm{ml}, 145.9 \pm 1.2$ mequiv. $/ 1$, and $5.0 \pm 0.1$ mequiv. $/ 1$, respectively.

Rat epididymal sperm concentrations increased from the rete fluid to the caput fluid to the cauda fluid (Table 1). This demonstrates that $89 \%$ of fluid leaving the rete testis is resorbed by the efferent ducts and proximal epididymidal tubule, and that $96 \%$ of the fluid leaving the rete is resorbed by the time the distal cauda epididymidis is reached (Table 1). This fluid resorption causes 
Table 1. Sperm concentrations (mean \pm s.e.) and fluid resorption from the rat epididymal duct

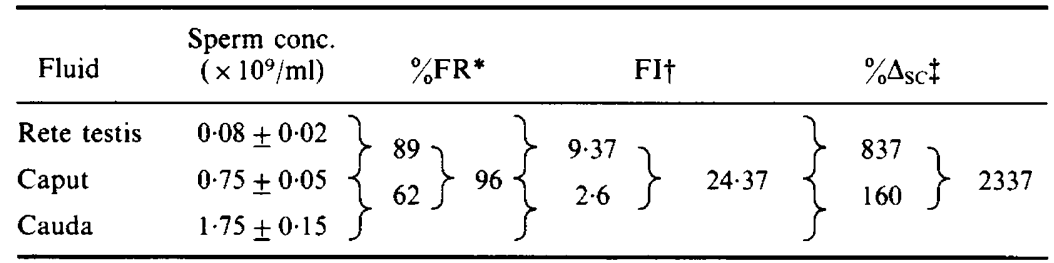

* Fluid resorption from zone to zone (Equation 2).

$\dagger$ Fold-increase in intraluminal sperm concentrations from zone to zone.

$\ddagger$ Increase in sperm concentrations from zone to zone (Equation 1).

Table 2. Protein, sodium and potassium concentrations and their secretion or absorption along the rat epididymis

\begin{tabular}{|c|c|c|c|c|}
\hline Substance & Fluid* & $\begin{array}{c}\text { Actual } \\
\text { conc. } \\
\text { (mean } \pm \text { s.e.) }\end{array}$ & Conc $_{D} \dagger$ & $\Delta_{\text {Conc }} \ddagger$ \\
\hline $\begin{array}{l}\text { Total protein } \\
(\mathrm{mg} / \mathrm{ml})\end{array}$ & $\begin{array}{l}\text { RTF } \\
\text { CPF } \\
\text { CDF }\end{array}$ & $\begin{array}{r}1 \cdot 2 \pm 0.0 \\
22 \cdot 4 \pm 4 \cdot 4 \\
28 \cdot 0 \pm 1 \cdot 5\end{array}$ & $\begin{array}{l}11 \cdot 2 \\
58 \cdot 2\end{array}$ & $\begin{array}{l}+11 \cdot 2 \\
-30 \cdot 2\end{array}$ \\
\hline $\begin{array}{l}\text { Sodium } \\
\quad \text { (mequiv./l) }\end{array}$ & $\begin{array}{l}\text { RTF } \\
\text { CPF } \\
\text { CDF }\end{array}$ & $\begin{array}{r}130.8 \pm 1.7 \\
101.8 \pm 3.2 \\
22.9 \pm 0.5\end{array}$ & $\begin{array}{r}1225 \cdot 6 \\
264 \cdot 7\end{array}$ & $\begin{array}{r}-1123 \cdot 8 \\
-241.8\end{array}$ \\
\hline $\begin{array}{l}\text { Potassium } \\
\quad \text { (mequiv./1) }\end{array}$ & $\begin{array}{l}\text { RTF } \\
\text { CPF } \\
\text { CDF }\end{array}$ & $\begin{array}{l}16.1 \pm 0.7 \\
27.6 \pm 1 \cdot 2 \\
52.4 \pm 0.9\end{array}$ & $\begin{array}{r}150.9 \\
71.8\end{array}$ & $\begin{array}{r}-123 \cdot 3 \\
-19 \cdot 4\end{array}$ \\
\hline
\end{tabular}

* RTF, rete testis fluid; CPF, caput epididymal fluid; CDF, cauda epididymal fluid.

$\dagger$ Predicted concentration in a zone based on concentration in previous zone and amount of fluid resorption between the two zones (Equation 4).

¥Difference between concentration predicted and concentration found indicating net secretion $(+)$ or absorption ( - ) of a substance (Equation 3).

a 9-fold increase in sperm cell concentrations between the rete testis and caput epididymidis and a 24-fold increase between rete testis and distal cauda epididymidis.

Total protein concentrations increased dramatically between the rete testis and the caput epididymidis, but only a slight increase occurred between caput and cauda epididymidis (Table 2). Predicted protein concentrations $\left(\widehat{\text {Conc}_{D}}\right.$ ) were exceeded in the caput fluid, thus indicating a net secretion of protein between rete testis and caput epididymidis. Conc for the cauda fluid protein was in excess of the total protein actually determined (Table 2) and indicated a net resorption of intraluminal proteins between the caput and cauda epididymidis.

Sodium concentrations declined between rete testis and caput epididymidis and again between caput and canda epididymidis (Table 2). Conc $_{\mathrm{D}}$ for sodium was always in excess of actual determinations, thus demonstrating a large resorption of sodium between the rete testis and caput epididymidis and further resorption between the caput and cauda epididymidis (Table 2).

Potassium concentrations increased with passage along the excurrent duct (Table 2). However, Conc $_{D}$ was always in excess of the actual concentrations found, demonstrating a net resorption of potassium.

\section{Discussion}

Intraluminal protein concentrations determined in the present study generally agree with previous estimates (Setchell et al., 1978; Turner et al., 1979). Sodium and potassium determinations also agree with previous findings (Levine \& Marsh, 1971; Jenkins et al., 1980) as do caput and cauda 
intraluminal sperm concentrations (Turner \& Cesarini, 1983). There do not appear to be any previous reports of rat rete testis sperm concentrations.

Apart from the data on sperm concentrations in the rete testis fluid, these findings by themselves are not new; however, specific attention to net loss or gain of a substance from the efferent ducts or epididymal lumen has received only minor consideration in the literature and the present calculations provide a new emphasis on this dynamic aspect of epididymal physiology. Key to the study was the use of intraluminal sperm concentrations as direct markers for intraluminal fluid space, and the demonstration that $96 \%$ of the fluid leaving the rete testis is resorbed by the time the co-migrating spermatozoa reach the cauda epididymidis indicates that one would expect $>2000 \%$ increase in any other intraluminal substance not diffused, metabolized or taken up by cells (total $\% \Delta_{\mathrm{SC}}=2337$; Table 1 ).

There is clearly a net secretion of proteins into the excurrent duct lumen between the rete testis and proximal caput epididymidis at the site of micropuncture sample collection (Table 2). This is shown by both the concentration data and the $\Delta_{\text {Conc }}$ determined. Despite a modest increase in intraluminal protein concentrations between the caput and cauda fluid, however, there is a large net loss of proteins $(30.2 \mathrm{mg} / \mathrm{ml}$ cauda fluid) from the epididymal lumen between these two regions. Appreciation of total protein losses is accentuated when one considers the greater lumen volume in the cauda epididymidis than in the caput epididymidis, a factor not estimated in the present study. This net loss of intraluminal proteins must be due in major part to resorption of protein. First, because it is accepted that intraluminal proteins do not diffuse from the epididymal lumen. This is due to a restriction of movement across the epididymal epithelium imposed by the bloodepididymal barrier, and even if the proteins could diffuse they would have to move against an uphill lumen-to-blood concentration gradient. Secondly, whilst intraluminal spermatozoa do acquire proteins from the epididymal lumen fluid (Brooks \& Higgins, 1980; Vernon et al., 1982), it has been shown in the ram that there are also losses of sperm-associated proteins into the lumen fluid (Dacheaux \& Voglmayr, 1983), and the net effect of this exchange on total protein in epididymal fluid appeared negligible in the ram (Dacheaux \& Voglmayr, 1983) and the rat (Brooks, 1983). Thirdly, no evidence has been found that intraluminal proteins are simply dissolved in situ. Previous studies with other species (Dacheaux \& Voglmayr, 1983) report no evidence of proteolysis of collected intraluminal fluids, and empirical observation from this laboratory is that in-situ proteolysis of stored micropuncture samples is not sufficient to change even electrophoretic patterns of intraluminal proteins. Even if there were some protein degradation in situ, it is unlikely that this would be accounted as a protein loss in the present study since the Lowry assay would still account for peptide-bonded aromatic amino acids present in the lumen. Finally, previous electron microscopical investigations (Nicander, 1965; Moore \& Bedford, 1979) have demonstrated that the epididymal epithelium will take up injected proteins by endocytosis.

The efferent ducts and epididymal tubules actively remove sodium from the duct lumen (Levine \& Marsh, 1971; Hohlbrugger, 1980). The net amount of this resorption has not previously been calculated, however, and the present results demonstrate the magnitude of the resorption of sodium between rete testis and caput epididymidis (1123.8 mequiv./1) compared with the relatively slight absolute concentration decrease between rete testis fluid $(\sim 131$ mequiv./l) and caput fluid $(\sim 102$ mequiv./l).

Potassium concentrations have also been previously shown to increase throughout the male excurrent duct system (Levine \& Marsh, 1971), but the present data demonstrate that there is actually a net resorption, not secretion, of potassium between the rete testis and the caput epididymidis, and again between the caput and cauda epididymidis (Table 2). Thus, these results demonstrate that there is a net resorption of proteins and potassium from the epididymal lumen despite increases in intraluminal concentrations of both these substances.

Previous studies have shown that carnitine (Hinton et al., 1979), myo-inositol (Hinton et al., 1980), and glycerophosphocholine and other phosphorus-containing compounds (Hinton \& Setchell, 1980) increase in concentrations from the proximal to the distal epididymis. These 
investigators used intraluminal spermatocrit as an indicator of intraluminal sperm concentration and demonstrated that inositol and glycerophosphocholine experience a net removal from the luminal fluids in various parts of the rat epididymis, whereas carnitine (Setchell \& Hinton, 1981) experiences net secretion distal to the proximal caput epididymidis. Spermatocrit observations are error-prone due to plasma-trapping effects and the use of different $\boldsymbol{g}$ forces and times in centrifugations at different laboratories. If the actual sperm concentration data of the present study are used with the previously reported concentrations of glycerophosphocholine, inositol and carnitine, it becomes very clear that removal from the lumen fluid is an important factor affecting the concentrations of inositol between the rete and caput $\left(\Delta_{\text {conc }}=-14.6 \mathrm{mM}\right)$ and of glycerophosphocholine between the caput and cauda $\left(\Delta_{\text {conc }}=-63.0 \mathrm{~mm}\right)$. Carnitine gives evidence for net secretion only between the caput and cauda ( $\Delta_{\text {conc }}=48.5 \mathrm{~mm}$ ).

In conclusion, the present results demonstrate that the epididymal tubule has a large resorptive function with regard to protein, sodium and potassium. Furthermore, application of the present fluid resorption data to other results in the literature corroborate that other organic compounds known to be secreted into the rat epididymis are also removed from the lumen fluid in relatively large amounts. Glycerophosphocholine and inositol may, of course, be removed from luminal fluid by uptake by spermatozoa or degradation in situ but there is no evidence that this occurs. It therefore seems that this resorptive function is an important aspect of how the epididymal tubule controls its intraluminal environment. A more complete understanding of epididymal physiology must include knowledge of the resorptive function of the epididymis as well as its more intensely studied secretory function.

I thank Herman Hernandez and George Reich for technical assistance. This work was supported by NIH grant HD14366.

\section{References}

Brooks, D.E. (1983) Epididymal functions and their hormonal regulation. Aust. J. biol. Sci. 36, 205-221.

Brooks, D.E. \& Higgins, S.J. (1980) Characterization and androgen-dependence of proteins associated with luminal fluid and spermatozoa in the rat epididymis. J. Reprod. Fert. 59, 363-375.

Cooper, T.G. (1980) The general importance of proteins and other factors in the transfer of steroids into the rat epididymis. Int. J. Androl. 3, 333-348.

Dacheux, J.L. \& Voglmayr, J.K. (1983) Sequence of sperm cell surface differentation and its relationship to exogenous fluid proteins in the ram epididymis. Biol. Reprod. 29, 1033-1046.

Flickinger, C.J. (1981) Regional differences in synthesis, intracellular transport, and secretion of protein in the mouse epididymis. Biol. Reprod. 25, 871-885.

Hinton, B.T. \& Howards, S.S. (1981) Permeability characteristics of the epithelium in the rat caput epididymidis. J. Reprod. Fert. 63, 95-99.

Hinton, B.T. \& Setchell, B.P. (1980) Concentrations of glycerylphosphocholine, phosphocholine, and free inorganic phosphate in the luminal fluid of the rat testis and epididymis. J. Reprod. Fert. 58, 401-406.

Hinton, B.T., Snoswell, A.M. \& Setchell, B.P. (1979) The concentration of carnitine in the luminal fluid of the testis and epididymis of the rat and some other mammals. J. Reprod. Fert. 56, 105-111.

Hinton, B.T., White, R.W. \& Setchell, B.P. (1980) Concentration of myo-inositol in the luminal fluid of the mammalian testis and epididymis. J. Reprod. Fert. 58, 395-399.

Hohlbrugger, G. (1980) A micropuncture study of transepithelial water resorption in rat ductuli efferentes. Fert. Steril. 34, 50-54.

Howards, S.S., Johnson, A.L. \& Jessee, S.J. (1975) Micropuncture and microanalytic studies of the rat testis and epididymis. Fert. Steril. 26, 13-19.

Jenkins, A.D., Lechene, C.P. \& Howards, S.S. (1980) Concentrations of seven elements in the intraluminal fluids of the rat seminiferous tubules, rete testis, and epididymis. Biol. Reprod. 23, 981-987.

Lea, O.A., Petrusz, P. \& French, F.S. (1978) Purification and localization of acidic epididymal glycoprotein (AEG): a sperm coating protein secreted by the rat epididymis. Int. J. Androl., Suppl. 2, 592-607.

Levine, N. \& Marsh, D.J. (1971) Micropuncture studies of the electrochemical aspects of fluid and electrolyte transport in individual seminiferous tubules, the epididymis, and the vas deferens of the rat. $J$. Physiol., Lond. 213, 557-570.

Lowry, O.H., Rosebrough, N.J., Farr, A.L. \& Randall, R.J. (1951) Protein measurement with the Folin phenol reagent. J. biol. Chem. 193, 265-275.

Moore, H.D.M. (1980) Localization of specific glycoproteins secreted by the rabbit and hamster epididymis. Biol. Reprod. 22, 705-718.

Moore, H.D.M. \& Bedford, J.M. (1979) The differential absorptive activity of epithelial cells of the rat 
epididymis before and after castration. Anat. Rec. 193, 313-328.

Nicander, L. (1965) An electron microscopical study of the absorbing cells in the posterior caput epididymis of rabbits. Z. Zellforsch. mikrosk. Anat. 66, 829847.

Orgebin-Crist, M.C. (1969) Studies on the function of the epididymis. Biol. Reprod. 1, 155-175.

Setchell, B.P. \& Hinton, B.T. (1981) The effects on the spermatozoa of changes in the composition of luminal fluid as it passes along the epididymis. Prog. Reprod. Biol. 8, 58-66.

Setchell, B.P., Davies, R.V., Gladwell, R.T., Hinton, B.T., Main, S.J., Pilsworth, L. \& Waties, G.M.H. (1978) The movement of fluid in the seminiferous tubules and rete testis. Annls Biol. anim. Biochim. Biophys. 18, 623-632.

Turner, T.T. (1979) On the epididymis and its function. Invest. Urol. 16, 311-321.
Turner, T.T. \& Cesarini, D.M. (1983) An investigation into the effects of aldosterone on the ability of the rat epididymis to concentrate spermatozoa. $J$. Androl. 4, 197-202.

Turner, T.T., Plesums, J.L. \& Cabot, C.L. (1979) Luminal fluid proteins of the male rat reproductive tract. Biol. Reprod. 21, 883-890.

Tumer, T.T., D'Addario, D.A. \& Howards, S.S. (1981) The blood epididymal barrier to $\left[{ }^{3} \mathrm{H}\right]$ inulin in intact and vasectomized hamsters. Invest. Urol. 19, 89-91.

Vernon, R.B., Muller, C.H., Herr, J.C., Feuchter, F.A. \& Eddy, E.M. (1982) Epididymal secretion of a mouse sperm surface component recognized by monoclonal antibody. Biol. Reprod. 26, 523-535.

Wong, P.Y.D. \& Yeung, C.H. (1977) Hormonal control of fluid reabsorption in isolated rat cauda epididymidis. Endocrinology 101, 1391-1397.

Received 27 March 1984 